\title{
Effect of Yeast Fermentation of Green Coffee Beans on Antioxidant Activity and Consumer Acceptability
}

\author{
Han Sub Kwak $\mathbb{D},{ }^{1}$ Yoonhwa Jeong $\mathbb{D}^{2},{ }^{2}$ and Misook Kim $\mathbb{D}^{2}$ \\ ${ }^{1}$ Division of Functional Food Research, Korea Food Research Institute, 245 Nongsaengmyeong-ro, Iseo-myeon, Wanju-gun, \\ Jeollabuk-do 55365, Republic of Korea \\ ${ }^{2}$ Department of Food Science and Nutrition, Dankook University, 19 Dandae-ro, 119 Dongnam-gu, Cheonan-si, \\ Chungnam 31116, Republic of Korea \\ Correspondence should be addressed to Misook Kim; mkim5@dankook.ac.kr
}

Received 16 November 2017; Accepted 23 January 2018; Published 6 March 2018

Academic Editor: Gabriel Henrique Horta de Oliveira

Copyright (C) 2018 Han Sub Kwak et al. This is an open access article distributed under the Creative Commons Attribution License, which permits unrestricted use, distribution, and reproduction in any medium, provided the original work is properly cited.

This study assessed the functionality and consumer acceptance of yeast fermented coffee beans. Green coffee beans were fermented for $24 \mathrm{~h}$ with three different yeast strains to increase functionality. The yeast fermentation was effective in fortifying the functionality of coffee by significantly increasing antioxidant activity according to the results of ORAC and SOD-like assay $(P<0.05)$. The TPC and TFC contents in the fermented coffee beans were significantly higher than those in the controls $(P<0.05)$. The consumer acceptance for the fermented coffee beans was slightly lower than that of the controls. Fermentation seemed to influence the aroma and flavor of coffee. However, agglomerative hierarchical clustering analysis revealed that approximately $39 \%$ of consumers significantly liked one of the fermented coffees (F3) more than the controls $(P<0.05)$. These consumers indicated that the yeast fermentation of green coffee beans did not generate a negative aroma or flavor and can be attractive with high antioxidant activity.

\section{Introduction}

Coffee is one of the most traded commodities worldwide. It is harvested in tropical regions and mostly exported to developed countries such as the USA, Europe, Russia, Japan, and Korea [1,2]. Many coffee drinkers consume coffee on a regular basis, similar to tea, and coffee is regarded as a hedonic food. However, coffee contains significant amounts of phenolic compounds such as chlorogenic and hydroxycinnamic acids and antioxidants including caffeine, melanoidins, and other Maillard reaction products and volatile compounds [3-5]. Levels of chlorogenic and hydroxycinnamic acids are also determined on the final aroma and taste of the roasted coffee $[6,7]$. Richelle et al. [8] demonstrated that a cup of Robusta and Arabica coffee had two times more antioxidant activity than a cup of green and black tea. A cup of coffee per day was found to reduce the relative risk of diabetes by $7 \%$ in meta-analysis [9] and moderate coffee drinking (below 4 cups per day) showed the strongest inverse relation to heart failure [10]. In some European countries, coffee is one of the major sources of antioxidants in the human diet [11-13].
The functionality of food products can be increased by fermentation. Ginseng is one of the best known functional foods. Ginsenoside contents and SOD-like activity after fermentation were significantly increased by solid-microbial fermentation of white ginseng $[14,15]$. Increased antioxidant activities and phenolic compounds are also frequently observed in fermented tea products. Jayabalan et al. [16] showed an increase in epicatechin isomers over 18 days of kombucha tea fermentation. DPPH radical scavenging activity and total polyphenol content in $\mathrm{Pu}$-Erh tea were significantly increased by fermentation [17].

The fermentation of coffee is known as coffee cherry fermentation and effectively removes the mucilage layer prior to the drying process for obtaining green coffee beans [18]. Therefore, the primary objective of coffee cherry fermentation is to improve the ease of obtaining green coffee beans rather than to increase the functionality of the coffee beans. Green coffee beans can gain higher functionality with additional processing steps such as soaking in fruit extracts and fermentation. Lim et al. [19] reported higher antioxidant activity, total polyphenol contents, and consumer 
acceptability after soaking green coffee beans in mulberry extract. However, the fermentation of green coffee beans has not been widely studied as a second processing step for increasing antioxidant activity and phenolic compounds. As the fermentation of tea products increases their antioxidant activity and the number of phenolic compounds, the antioxidant activity and phenolic compounds in green coffee beans could also be increased by fermentation. The fermented coffee beans can become fortified functional coffee beans. Therefore, the objective of this study was to ferment green coffee beans using commercial yeasts and investigate the resulting physicochemical properties, antioxidant activity, total polyphenol and flavonoid contents, and consumer acceptability with the intention of making fortified functional coffee beans.

\section{Materials and Methods}

2.1. Chemicals. Sodium carbonate $\left(\mathrm{Na}_{2} \mathrm{CO}_{3}\right)$, sodium nitrite $\left(\mathrm{NaNO}_{2}\right)$, monosodium phosphate $\left(\mathrm{NaH}_{2} \mathrm{PO}_{4}\right)$, disodium phosphate $\left(\mathrm{Na}_{2} \mathrm{HPO}_{4}\right)$, potassium acetate $\left(\mathrm{CH}_{3} \mathrm{COOK}\right)$, and aluminum chloride $\left(\mathrm{AlCl}_{3} \cdot 6 \mathrm{H}_{2} \mathrm{O}\right)$ were purchased from Duksan Pure Chemicals (Ansan-si, Korea). $\mathrm{HCl}, \mathrm{NaCl}$, ethanol, and methanol were supplied by Samchun Pure Chemicals (Pyeongtaek-si, Korea). D-Glucose was bought from Duchefa Biochemie BV (Haarlem, Netherlands). YPD was purchased from Becton Dickinson (Sparks, MD, USA). Folin-Ciocalteu's phenol reagent, fluorescein sodium, $2,2^{\prime}$-azobis $(2$-amidinopropane)dihydrochloride (AAPH), 2,5-dinitrosalicylic acid (DNS), trolox, ethylenediaminetetraacetic acid (EDTA), pyrogallol, quercetin, and gallic acid were supplied by SigmaAldrich LLC (St. Louis, MO, USA).

2.2. Coffee Fermentation, Roasting, and Brewing. Green coffee beans ( $300 \mathrm{~g}$; Brazil Ipanema Euro Natural, Coiners International Ltd., Bucheon-si, Korea) were put into a water $(450 \mathrm{~mL})$ and yeast $\left(3.75 \mathrm{~mL}, 1.0 \times 10^{7} \mathrm{CFU} / \mathrm{mL}\right)$ mixture. Three different commercial yeasts (Saccharomyces species) were used for fermentation: F1 (Lalvin 71B, Lallemand Inc., Montreal, Canada), F2 (Lalvin Cy3079, Lallemand Inc.), and F3 (BDX, Lallemand Inc.). Fermentation was conducted for $24 \mathrm{~h}$ at $30^{\circ} \mathrm{C}$. After fermentation, green coffee beans were washed three times using sterile water. The fermented coffee beans were dried in a dry oven at $45^{\circ} \mathrm{C}$ until their moisture content reached $10 \%$. Two controls were used in this study; one control $(\mathrm{Cl})$ was the original green coffee beans and the other was a control (C2) treated with the same procedure as the yeast fermented coffee beans but without yeasts.

Coffee roasting was conducted with an automatic coffee roaster to ensure a similar roasting condition for all green coffee beans (Behmor 1600, Behmor Inc., Incline Village, NV, USA). The green coffee beans were put into the roaster and roasted at maximum heating power $(1,600 \mathrm{~W})$ for $16 \mathrm{~min}$. The roasted coffee beans were cooled for $15 \mathrm{~min}$ and kept at room temperature for three days. The roasted coffee beans were ground using the medium option on a coffee grinder (KG79, De'Longhi, Milano, Italy). The ground coffee (36g) was brewed with $600 \mathrm{~mL}$ of filtered water using a coffee maker (HD7564, Philips, Netherlands).
2.3. Fermentation Characteristics. The $\mathrm{pH}$ of the fermentation solution was measured using an electronic $\mathrm{pH}$ meter (Orion 3 star, Thermo Fisher Scientific Inc., Waltham, MA, USA) at 0 and $24 \mathrm{~h}$.

The reducing sugar content in the green coffee beans was determined by the DNS method [20] with some modifications. A sample $(200 \mathrm{uL})$ was mixed with $600 \mathrm{uL}$ DNS solution and heated at $100^{\circ} \mathrm{C}$ for $5 \mathrm{~min}$. Water $(3 \mathrm{~mL})$ was added to the reaction solution and its absorbance was measured at $550 \mathrm{~nm}$. D-Glucose solutions $(0.1-2.5 \mathrm{mg} / \mathrm{mL})$ were used for a standard curve $(R=0.997)$.

Yeast-containing solutions for green coffee bean fermentation were serially diluted with $0.85 \% \mathrm{NaCl}$ solution and spread onto the surface of YPD agar plates. The spread plates were incubated for $24 \mathrm{~h}$ at $30^{\circ} \mathrm{C}$ to determine the total microbial counts.

2.4. Physicochemical Characteristics of Roasted Coffee. Moisture content determination was performed according to the Association of Official Agricultural Chemists [21] guidelines. Approximately $1 \mathrm{~g}$ of ground coffee beans was dried at $105^{\circ} \mathrm{C}$ after roasting until the weight became consistent.

Crude ash content was also measured with the Association of Official Agricultural Chemists [21] guidelines. The roasted coffee beans $(1 \mathrm{~g})$ were incinerated at $550^{\circ} \mathrm{C}$ until the weight became consistent. Crude ash content was determined gravimetrically.

The color of the ground coffee after roasting was measured using a Hunter colorimeter system (JC-801S, Color Techno system Co., Tokyo, Japan). Ground coffee ( $2 \mathrm{~g})$ was put into a small Petri dish for measurement. Lightness $(L)$, redness $(a)$, and yellowness $(b)$ were measured. $L, a$, and $b$ values for the standard white color plate were $L=98.38, a=$ 0.29 , and $b=-0.41$, respectively.

2.5. Antioxidant Activity. Oxygen radical absorbance capacity (ORAC) was measured using the method described by $\mathrm{Ou}$ et al. [22] with some modifications for in vitro antioxidant activity. Phosphate $\left(\mathrm{NaH}_{2} \mathrm{PO}_{4}-\mathrm{Na}_{2} \mathrm{HPO}_{4}\right)$ buffer $(10 \mathrm{mM}, \mathrm{pH}$ 7.0) was used to dissolve fluorescein powder. Coffee extract $(50 \mu \mathrm{L})$ and $25 \mathrm{mM}$ fluorescein solution $(150 \mu \mathrm{L})$ were mixed and then incubated in a dark room for $10 \mathrm{~min}$. A volume of $25 \mu \mathrm{L}$ of $120 \mathrm{mM}$ AAPH solution was added to the coffee extract and fluorescein mixture. The control was $10 \mathrm{mM}$ phosphate buffer instead of coffee extract. Fluorescence was measured by the microplate reader (Spectra max M2, Molecular Devices, LLC., Sunnyvale, CA, USA). Measurements were taken every minute for $90 \mathrm{~min}$ (excitation wavelength: $485 \mathrm{~nm}$; emission wavelength: $535 \mathrm{~nm}$ ). The ORAC values were calculated by the following formula and presented as $\mu \mathrm{M}$ trolox equivalent $/ \mathrm{mL}$ of coffee $(\mu \mathrm{M} \mathrm{TE} / \mathrm{mL})$ :

$$
\begin{aligned}
& \operatorname{ORAC}(\mu \mathrm{M} \mathrm{TE} / \mathrm{g}) \\
& =\frac{C_{\text {Trolox }} \times\left(\mathrm{AUC}_{\text {Sample }}-\mathrm{AUC}_{\text {Blank }}\right) \times k}{\left(\mathrm{AUC}_{\text {Trolox }}-\mathrm{AUC}_{\text {Blank }}\right)},
\end{aligned}
$$

where $C_{\text {Trolox }}, k$, and AUC were the concentration of trolox $(5 \mu \mathrm{M})$, the sample dilution factor, and the area under 
TABLE 1: Change of $\mathrm{pH}$, reducing sugar, and viable cells before and after fermentation.

\begin{tabular}{lcccccc}
\hline \multirow{2}{*}{ Sample } & \multicolumn{2}{c}{$\mathrm{pH}$} & \multicolumn{2}{c}{ Reducing sugar $(\mathrm{mg} / \mathrm{mL})$} & \multicolumn{2}{c}{ Viable cell count $(\log \mathrm{CFU} / \mathrm{mL})$} \\
& $0 \mathrm{~h}$ & $24 \mathrm{~h}$ & $0 \mathrm{~h}$ & $24 \mathrm{~h}$ & $0 \mathrm{~h}$ & $24 \mathrm{~h}$ \\
\hline $\mathrm{C} 2$ & 5.98 & 5.13 & $0.68 \pm 0.01^{\mathrm{c}(1)}$ & $2.57 \pm 0.13^{\mathrm{a}}$ & $<1.16 \pm 0.53$ & $9.78 \pm 0.70^{\mathrm{a}}$ \\
F1 & 5.79 & 4.92 & $1.12 \pm 0.02^{\mathrm{b}}$ & $2.51 \pm 0.12^{\mathrm{a}}$ & $6.50 \pm 5.83$ & $9.85^{\mathrm{a}}$ \\
F2 & 5.93 & 4.52 & $1.28 \pm 0.03^{\mathrm{a}}$ & $2.47 \pm 0.09^{\mathrm{a}}$ & $6.41 \pm 5.62$ & $9.25 \pm 0.86^{\mathrm{a}}$ \\
F3 & 5.78 & 5.04 & $1.12 \pm 0.01^{\mathrm{b}}$ & $2.67 \pm 0.09^{\mathrm{a}}$ & $6.30 \pm 5.30$ & $9.03 \pm 0.81^{\mathrm{b}}$ \\
\hline
\end{tabular}

${ }^{(1)}$ Different superscripts within a column meant significant difference at $P<0.05$ by Fisher's least significant difference test.

the curve, respectively. AUC was calculated based on the following formula:

$$
\mathrm{AUC}=1+\sum_{n=1}^{90} \frac{f_{n}}{f_{0}}
$$

where $f_{n}$ is the fluorescence at time $n(\mathrm{~min})$.

Superoxide dismutase-like (SOD-like) activity was determined using the method described by S. Marklund and G. Marklund [23] with some modifications. Coffee extract $(400 \mu \mathrm{L})$, Tris- $\mathrm{HCl}$ buffer $(600 \mu \mathrm{L}, 50 \mathrm{mM}$ tris(hydroxymethyl)aminomethane and $10 \mathrm{mM}$ ethylenediaminetetraacetic acid (EDTA), $\mathrm{pH} 8.0$ ), and $7.2 \mathrm{mM}$ pyrogallol $(40 \mu \mathrm{L})$ were mixed together and kept at $25^{\circ} \mathrm{C}$ for $10 \mathrm{~min}$. The reaction was stopped by adding $0.1 \mathrm{~N} \mathrm{HCl}(20 \mu \mathrm{L})$. The absorbance was measured at $420 \mathrm{~nm}$ using a UV/visible spectrophotometer (Ultrospec 2100 Pro, Biochrom Ltd., Cambridge, UK). SODlike activity was calculated based on the following equation:

$$
\text { SOD-like activity }(\%)=\left(1-\frac{A}{B}\right) \times 100,
$$

where $A$ is absorbance of the sample and $B$ is absorbance of the control.

2.6. Total Polyphenol and Flavonoid Contents. The total polyphenol content (TPC) of brewed coffee was measured using Singleton's method [24] with some modifications. Coffee extract $(20 \mu \mathrm{L})$ was diluted with $1,580 \mu \mathrm{L}$ of distilled water. Diluted coffee $(160 \mu \mathrm{L})$ was mixed with Folin-Ciocalteu's phenol reagent $(10 \mu \mathrm{L})$ and allowed to sit for $8 \mathrm{~min}$. A volume of $30 \mu \mathrm{L}$ of $20 \% \mathrm{Na}_{2} \mathrm{CO}_{3}$ solution was added and the mixture was incubated in a dark room for $2 \mathrm{~h}$. Distilled water instead of coffee extract was used as a control. The absorbance was measured at $765 \mathrm{~nm}$ by a microplate reader (Spectra max M2, Molecular Devices, LLC.). Gallic acid solutions $(0-1 \mathrm{mg} / \mathrm{mL})$ were used to generate a standard curve $\left(R^{2}=0.997\right)$. The results were presented as $\mathrm{mg}$ gallic acid equivalent $/ \mathrm{mL}$ of coffee extract (mg GAE/mL).

The total flavonoid content (TFC) for each coffee extract was evaluated according to the method described by Dewanto study with some modifications [25]. Coffee extract $(250 \mu \mathrm{L})$, distilled water $(1 \mathrm{~mL})$, and $75 \mu \mathrm{L}$ of $5 \% \mathrm{NaNO}_{2}$ were mixed together. After $5 \mathrm{~min}, 10 \% \mathrm{AlCl}_{3} \cdot 6 \mathrm{H}_{2} \mathrm{O}$ solution $(150 \mu \mathrm{L})$ was added and incubated for $6 \mathrm{~min} .1 \mathrm{~N} \mathrm{NaOH}(500 \mu \mathrm{L})$ was injected, and the mixture was incubated for $11 \mathrm{~min}$. A blank sample was substituted for the diluted coffee extract with distilled water. The absorbance of the sample was measured at $510 \mathrm{~nm}$ against the blank sample using a microplate reader (Spectra max M2, Molecular Devices, LLC). The difference in absorbance between the sample and the blank was compared to the absorbance of the quercetin solution used as the positive control $\left(R^{2}=0.999\right)$. The amount of flavonoids in the coffee was presented as $\mathrm{mg}$ quercetin equivalent $/ \mathrm{mL}$ of coffee extract.

2.7. Consumer Acceptance Test. The consumer acceptance test for the yeast fermented coffee was performed with 74 subjects (24 males and 50 females, ages 19-30) who were students and staff at Dankook University (Yongin-si, Korea). Subjects were coffee drinkers that consumed Americano coffee (espresso coffee extract + hot water) at least once a week. Consumer testing was conducted in an open area under incandescent lighting. Subjects were assigned to tables and were prohibited from talking and using cellphones during the test. Coffee $(20 \mathrm{~mL})$ was served in $60 \mathrm{~mL}$ paper cups using a completed balanced design [26] in order to minimize carryover effects. The temperature of the coffee was approximately $60^{\circ} \mathrm{C}$. Acceptance of overall quality, coffee aroma, bitter taste, astringent taste, and smooth mouthfeel was rated using a nine-point hedonic scale on paper ballots. Each category on the scale was labeled with numbers and descriptors in order to give a clear understanding of the scale. Starting from the left side, the scale was labeled as $1=$ dislike extremely, $2=$ dislike very much, $3=$ dislike moderately, $4=$ dislike slightly, $5=$ neither like nor dislike, $6=$ like slightly, $7=$ like moderately, $8=$ like very much, and $9=$ extremely like. A cup of filtered water was served as a palate cleanser. Subjects were monetarily compensated after the test (approximately $\$ 8.5$ ).

2.8. Statistical Analyses. Results were analyzed using Excel integrated statistical software (XLSTAT version 2012, Addinsoft, Paris, France) in this study. Analysis of variance (ANOVA) was performed to identify significant differences across samples. Post hoc analysis was carried out using Fisher's least significant test at $P<0.05$ when the significance was observed by ANOVA. Agglomerative hierarchical clustering (AHC) analysis was conducted to generate consumer segment groups based on their overall quality ratings.

\section{Results and Discussion}

3.1. Fermentation Characteristics. Measurements of $\mathrm{pH}$ values, reducing sugar contents, and viable cell counts were conducted to investigate the effect of yeast fermentation on green coffee beans (Table 1). Reducing sugar contents for 
TABLE 2: Moisture content, crude ash, and color of ground roasted coffee beans after $24 \mathrm{~h}$ of yeast fermentation.

\begin{tabular}{|c|c|c|c|c|c|c|}
\hline \multirow{2}{*}{ Sample } & \multirow{2}{*}{ Moisture content (\%) } & \multirow{2}{*}{ Crude ash (\%) } & \multicolumn{4}{|c|}{ Color } \\
\hline & & & $L$ & $a$ & $b$ & $\Delta E$ \\
\hline $\mathrm{C} 1$ & $1.50 \pm 0.09^{\mathrm{a}(1)}$ & $4.73 \pm 0.05^{\mathrm{a}}$ & $31.52 \pm 1.01^{\mathrm{a}}$ & $7.91 \pm 0.44^{\mathrm{a}}$ & $16.78 \pm 1.92^{\mathrm{a}}$ & $69.60 \pm 1.27^{\mathrm{b}}$ \\
\hline $\mathrm{C} 2$ & $1.30 \pm 0.05^{\mathrm{b}}$ & $4.08 \pm 0.06^{\mathrm{cd}}$ & $25.24 \pm 0.62^{c}$ & $4.90 \pm 0.25^{\mathrm{b}}$ & $8.70 \pm 0.89^{c}$ & $74.00 \pm 0.62^{\mathrm{a}}$ \\
\hline $\mathrm{F} 1$ & $1.27 \pm 0.17^{\mathrm{b}}$ & $4.05 \pm 0.06^{\mathrm{d}}$ & $30.62 \pm 0.81^{\mathrm{ab}}$ & $7.11 \pm 0.94^{\mathrm{a}}$ & $14.74 \pm 0.80^{\mathrm{ab}}$ & $69.91 \pm 0.52^{\mathrm{b}}$ \\
\hline $\mathrm{F} 2$ & $1.23 \pm 0.06^{\mathrm{b}}$ & $4.15 \pm 0.05^{\mathrm{c}}$ & $25.17 \pm 0.68^{c}$ & $4.43 \pm 0.26^{\mathrm{b}}$ & $7.63 \pm 0.53^{c}$ & $73.90 \pm 0.61^{\mathrm{a}}$ \\
\hline F3 & $1.31 \pm 0.10^{\mathrm{b}}$ & $4.40 \pm 0.05^{\mathrm{b}}$ & $29.78 \pm 0.97^{\mathrm{b}}$ & $6.97 \pm 0.54^{\mathrm{a}}$ & $13.75 \pm 1.08^{\mathrm{b}}$ & $70.51 \pm 0.70^{b}$ \\
\hline
\end{tabular}

${ }^{(1)}$ Different superscripts within a column meant significant difference at $P<0.05$ by Fisher's least significant difference test.

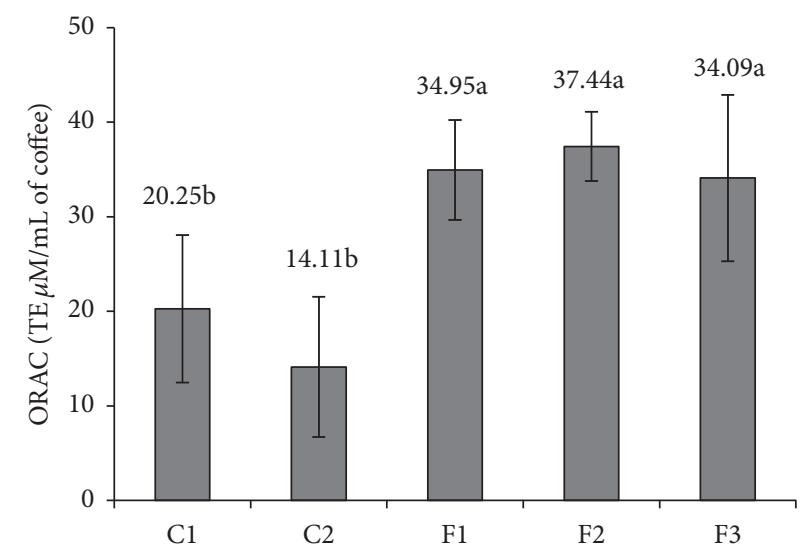

(a)

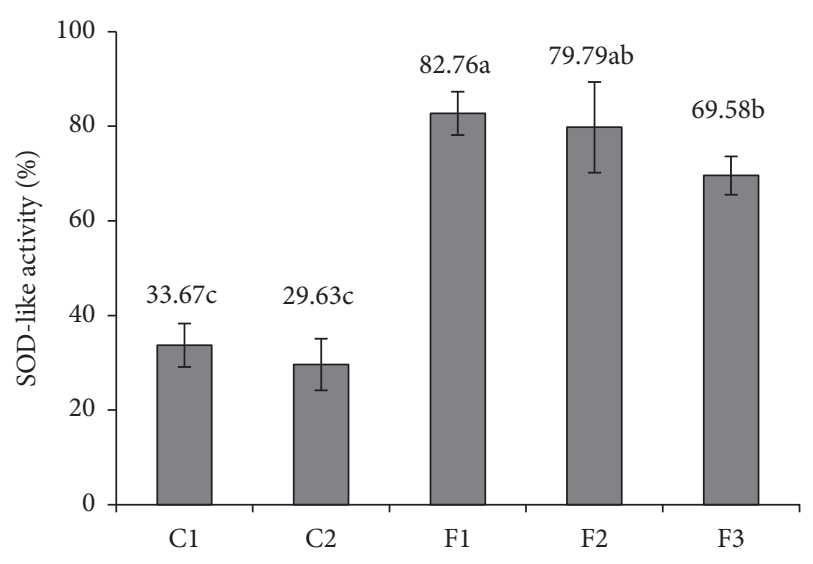

(b)

FIGURE 1: Antioxidant activities of yeast fermented coffee extracts by oxygen radical absorbance capacity (a) and superoxide dismutase-like (SOD-like) activity (b) assays. Different letters meant significant difference at $P<0.05$ by Fisher's least significant difference test.

C2, F1, F2, and F3 were 2.567, 2.507, 2.469, and $2.673 \mathrm{mg}$. $\mathrm{pH}$ decreased after $24 \mathrm{~h}$ of fermentation. The $\mathrm{pH}$ for $\mathrm{C} 2$ also decreased. This decrease would be due to the soluble organic acids released from green coffee beans [27] and produced by the fermentation of naturally occurring lactic acid bacteria in coffee beans. After $24 \mathrm{~h}$ of fermentation, there was no significant difference in reducing sugar content in the fermented solution $(P>0.05)$. Viable cell counts for $\mathrm{C} 2$, F1, F2, and F3 showed that fermentation was conducted by yeasts (Table 1). The initial number of viable microbial cells was less than $1.16 \log \mathrm{CFU} / \mathrm{mL}$. The number of microbial cells, naturally present in green coffee beans, increased to $7.78 \mathrm{CFU} / \mathrm{mL}$ after $24 \mathrm{~h}$ fermentation. Solutions from F1, F2, and F3, fermented by starter culture, showed approximately 2.5 higher $\log \mathrm{CFU} / \mathrm{mL}$ of solution than that from C2. This provided supporting evidence for the proliferation of yeasts during fermentation and the role of yeasts in the fermentation. Throughout the $24 \mathrm{~h}$ of fermentation, there was no drastic change in $\mathrm{pH}$ and reducing sugar content; hence yeast fermentation occurred across all samples.

3.2. Quality Characteristics of Fermented Coffee Beans. The moisture content, crude ash, and color of fermented coffee beans after roasting are presented in Table 2. No significant difference across fermented coffee beans and C2 was observed. This indicates that the drying and roasting of the fermented green coffee beans were performed identically. The moisture content of $\mathrm{C} 1$ was $1.50 \%$ and was significantly higher than those of $\mathrm{C} 2$ and the fermented coffee beans $(P<0.05)$. This was due to slight overdrying prior to roasting. The ash content was also significantly higher in $\mathrm{C} 1$ at $4.73 \%$, while the others ranged from 4.05 to $4.40 \%$. Moisture content and crude ash showed a strong negative correlation $(R=0.894$, $P=0.041)$. The color of the ground roasted coffee beans showed differences across the samples. C1, F1, and F3 had higher $L, a$, and $b$ values and lower $\Delta E$ values than $C 2$ and F2. The color of the ground coffee beans showed a different pattern in comparison with the moisture content and crude ash. Therefore, the different colors of the roasted coffee beans likely partially originated from the fermentation as well as the difference in moisture contents.

3.3. Antioxidant Activity. The antioxidant activities of the coffee extracts in ORAC and SOD-like assays are shown in Figure 1. ORAC for the yeast fermented coffee extracts were $34.95,37.44$, and $34.09 \mu \mathrm{M} \mathrm{TE} / \mathrm{mL}$ for F1, F2, and F3, respectively (Figure 1(a)). ORAC for $\mathrm{Cl}$ and $\mathrm{C} 2$ were 20.25 and $14.11 \mu \mathrm{M} \mathrm{TE} / \mathrm{mL}$, respectively. There was no significant difference in ORAC values after soaking the green coffee beans for $24 \mathrm{~h}(P>0.05)$; however, a slight decrease in the ORAC value was observed in $\mathrm{C} 2$. It seemed that the soluble antioxidants in green coffee beans might be eluted into water. The ORAC values of the yeast fermented coffee extracts (F1, F2, and F3) were significantly higher than those from the controls $(\mathrm{C} 1$ and $\mathrm{C} 2)(P<0.05)$. There was no significant difference across the fermented coffee beans 


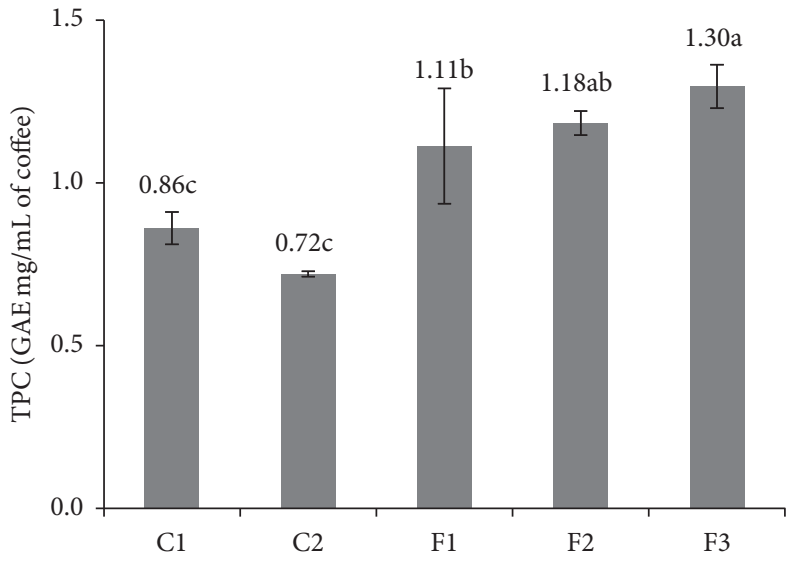

(a)

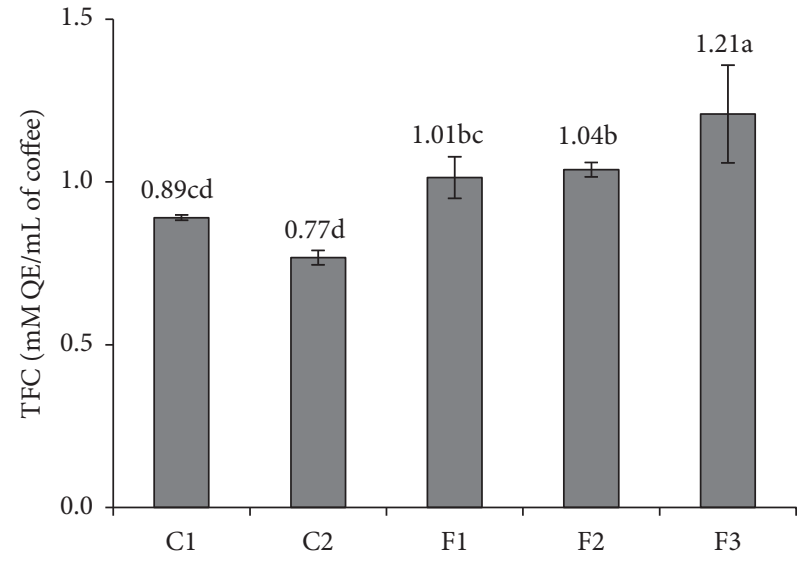

(b)

FIGURE 2: Total polyphenol (a) and flavonoid (b) contents of yeast fermented coffee extracts. Different letters meant significant difference at $P<0.05$ by Fisher's least significant difference test.

$(P<0.05)$. In SOD-like activity, F1, F2, and F3 showed $82.76,79.79$, and $69.58 \%$, respectively (Figure $1(\mathrm{~b})$ ). On the other hand, $\mathrm{C} 1$ and $\mathrm{C} 2$ showed 33.67 and $29.63 \%$ SOD-like activity, respectively, and were not significantly different $(P>$ 0.05). An increase of more than two times the SOD-like activity was observed after $24 \mathrm{~h}$ of yeast fermentation. Among the fermented samples, F1 showed the highest activity and the activity was significantly higher than F3 $(P<0.05)$. Soaking green coffee beans in water (C2) did not significantly influence the antioxidant activity of the coffee extracts $(P>$ 0.05 ) although the ORAC value of $\mathrm{C} 2$ was slightly lower than that of C1. Fermentation for $24 \mathrm{~h}$ was effective in increasing the antioxidant activity significantly. The increase of antioxidant activity by fermentation was similar to other fermented materials such as ginseng, garlic, tea, and soy $[15,16,28,29]$.

3.4. Total Polyphenol and Flavonoid Contents. The TPC and TFC of the yeast fermented coffee extracts are presented in Figure 2. The yeast fermented coffee extracts (F1, F2, and F3) had 1.11, 1.18, and 1.30 GAE mg/mL of coffee extract, respectively (Figure $2(\mathrm{a})$ ). F3 had significantly higher TPC than $\mathrm{F} 1(P<0.05)$. Control samples $(\mathrm{C} 1$ and $\mathrm{C} 2)$ had significantly lower amounts of TPC than the yeast fermented coffee extracts $(P<0.05)$. C2 had the lowest TPC at $0.72 \mathrm{GAE} \mathrm{mg} / \mathrm{mL}$. This was due to the elution of soluble phenolic compounds in the green coffee beans during the soaking period $(24 \mathrm{~h})$. A similar finding was observed after soaking green coffee beans in mulberry extract [19]. In Lim's study, the TPC of the coffee extracts decreased after $6 \mathrm{~h}$ of soaking. Despite the decrease in TPC due to the soaking process in this study, fermentation positively influenced TPC in the coffee extracts. During the fermentation process, strongly bound phenolic compounds in the cell wall may become weakened [30], making them easier to extract after roasting. Phenolic compounds in coffee are mostly in the forms of chlorogenic acids with 5-O-caffeoyl-quinic acid such as caffeic, ferulic, p-coumaric, and caffeoylquinic acid [3]. Feruloylquinic acid, di-caffeoyl-quinic acid, and proanthocyanidins are also detected in coffee [3].
In TFC, the yeast fermented coffee extracts (F1, F2, and F3) had 1.01, 1.04, and 1.21 QE mg/mL of coffee extract, respectively, and $\mathrm{F} 3$ had significantly higher $(P<0.05)$ TFC than F1 and F2 (Figure 2(b)). C1 and C2 had lower amounts of TFC than the yeast fermented coffee extracts. Yeast fermentation was effective in increasing the number of flavonoids in the coffee extracts. The increase in TFC might be due to the conversion of insoluble phenolic compounds into soluble flavonoids during fermentation [31]. The ratio of TFC to TPC in C1 and C2 was 1.03 and 1.07 , while F1, F2, and F3 had ratios of $0.91,0.88$, and 0.93 , respectively. The ratio was lower in the yeast fermented coffee extracts. Fermentation was more effective in producing soluble phenolic compounds than flavonoids. This result contrasted with those for fermented Columbian coffee [32]. However, Columbian coffee fermentation was conducted with broken green beans, which might elute more soluble phenolic compounds easily over seven days of fermentation. This would also influence the roasting process.

3.5. Consumer Acceptance Test. Consumer acceptance for the fermented and control coffee extracts is shown in Table 3. Mean overall quality rating was the highest in $\mathrm{Cl}$, followed by F3. F1 and F2 had significantly lower overall quality ratings than $\mathrm{Cl}$ at 4.35 and 4.43 , respectively $(P<0.05)$. $\mathrm{C} 2$ also received slightly lower overall quality ratings than $\mathrm{C} 1$. Therefore, the soaking process does appear to slightly influence the coffee quality. Color acceptance was not significantly different $(P<0.05)$, which meant that there was no difference in the appearance of the coffee extract. Aroma acceptance ratings for the fermented coffee samples (F1, F2, and F3) were significantly lower than those for the controls $(\mathrm{C} 1$ and $\mathrm{C} 2)(P<0.05)$. The consumer acceptability was within the range of the previous acceptance study using various roasting conditions [33]. Fermentation might negatively influence the aroma acceptance of coffee. Across the fermented coffee samples (F1, F2, and F3) the differences in consumer acceptability might be related to the presence of different volatile compounds in coffee beans after fermentation. Different yeasts showed different flavor profiles 
TABLE 3: Overall quality and acceptances of color, aroma, sourness, bitterness, astringency, and mouthfeel of yeast fermented coffee extract by 74 consumers.

\begin{tabular}{|c|c|c|c|c|c|c|c|}
\hline Sample & Overall quality & Color & Aroma & Sourness & Bitterness & Astringency & Mouthfeel \\
\hline $\mathrm{Cl}$ & $5.09 \pm 1.72^{\mathrm{a}(1)}$ & $5.59 \pm 1.76^{\mathrm{a}}$ & $5.62 \pm 1.63^{\mathrm{a}}$ & $5.12 \pm 1.86^{\mathrm{a}}$ & $4.51 \pm 1.90^{\mathrm{a}}$ & $4.81 \pm 1.80 \mathrm{a}$ & $5.80 \pm 1.75^{\mathrm{a}}$ \\
\hline $\mathrm{C} 2$ & $4.69 \pm 1.65^{\mathrm{ab}}$ & $5.30 \pm 1.75^{\mathrm{a}}$ & $5.12 \pm 1.70^{\mathrm{a}}$ & $5.07 \pm 1.49^{\mathrm{a}}$ & $4.12 \pm 1.94^{\mathrm{ab}}$ & $4.57 \pm 1.82^{\mathrm{ab}}$ & $5.35 \pm 1.68^{\mathrm{ab}}$ \\
\hline $\mathrm{F} 1$ & $4.35 \pm 1.70^{\mathrm{b}}$ & $5.18 \pm 1.48^{\mathrm{a}}$ & $4.08 \pm 1.85^{\mathrm{b}}$ & $4.78 \pm 1.50^{\mathrm{a}}$ & $3.84 \pm 1.76^{\mathrm{b}}$ & $4.20 \pm 1.76^{\mathrm{b}}$ & $4.99 \pm 1.72^{\mathrm{b}}$ \\
\hline $\mathrm{F} 2$ & $4.43 \pm 1.46^{\mathrm{b}}$ & $5.23 \pm 1.44^{\mathrm{a}}$ & $4.51 \pm 1.51^{\mathrm{b}}$ & $4.19 \pm 1.58^{\mathrm{b}}$ & $4.01 \pm 1.85^{\mathrm{ab}}$ & $4.03 \pm 1.79^{b}$ & $4.85 \pm 1.66^{\mathrm{b}}$ \\
\hline F3 & $4.84 \pm 1.67^{\mathrm{ab}}$ & $5.54 \pm 1.60^{\mathrm{a}}$ & $4.45 \pm 1.95^{\mathrm{b}}$ & $4.84 \pm 1.47^{\mathrm{a}}$ & $4.41 \pm 1.89^{\mathrm{ab}}$ & $4.36 \pm 1.58^{\mathrm{ab}}$ & $5.12 \pm 1.57^{\mathrm{b}}$ \\
\hline
\end{tabular}

${ }^{(1)}$ Different superscripts within a column meant significant difference at $P<0.05$ by Fisher's least significant difference test.

TABLE 4: Agglomerative hierarchical clustering (AHC) analysis of overall quality.

\begin{tabular}{lcccccc}
\hline Class & Subject $^{(1)}$ & $\mathrm{C} 1$ & $\mathrm{C} 2$ & $\mathrm{~F} 1$ & $\mathrm{~F} 2$ & $\mathrm{~F} 3$ \\
\hline 1 & 28 & $3.79 \pm 1.20^{\mathrm{b}(2)}{ }_{\mathrm{B}(3)}$ & $3.82 \pm 1.61^{\mathrm{b}}{ }_{\mathrm{B}}$ & $3.57 \pm 1.48^{\mathrm{b}}{ }_{\mathrm{B}}$ & $4.89 \pm 1.66^{\mathrm{a}}{ }_{\mathrm{A}}$ & $5.32 \pm 1.61^{\mathrm{a}}{ }_{\mathrm{A}}$ \\
2 & 43 & $5.95 \pm 1.53^{\mathrm{a}}{ }_{\mathrm{A}}$ & $5.23 \pm 1.49^{\mathrm{b}}{ }_{\mathrm{A}}$ & $4.81 \pm 1.72^{\mathrm{bc}}{ }_{\mathrm{A}}$ & $4.09 \pm 1.29^{\mathrm{d}}{ }_{\mathrm{B}}$ & $4.51 \pm 1.71^{\mathrm{cd}}{ }_{\mathrm{B}}$ \\
\hline
\end{tabular}

${ }^{(1)}$ Three subjects were removed from AHC analysis because they marked same ratings for entire samples. ${ }^{(2)}$ Different superscripts within a row meant significant difference at $P<0.05$ by Fisher's least significant difference test. ${ }^{(3)}$ Different subscripts within a column meant significant difference at $P<0.05$.

in rice distilled liquor [34] and cachaça [35]. Acceptance ratings for sourness, bitterness, astringency, and mouthfeel were lower in the yeast fermented coffee samples than in $\mathrm{Cl}$ and $\mathrm{C} 2$.

In order to segment consumers into a small number of groups, AHC analysis was performed using the overall quality ratings for all except three consumers that selected the same acceptance ratings for the entire sample (Table 4). Consumers were divided into two clusters generated by AHC analysis. Cluster 1 was composed of $39.4 \%$ of the total consumers. These were the consumers who preferred fermented coffee (F2 and F3), while disliking the controls (C1 and C2) $(P<$ $0.05)$. On the other hand, cluster 2 was composed of $60.6 \%$ of consumers. These consumers had higher overall quality ratings for the controls ( $\mathrm{C} 1$ and $\mathrm{C} 2$ ). They also rated $\mathrm{F} 1$ as an average of 4.81 and had the least acceptance for F2 at 4.09. Approximately $40 \%$ of consumers preferred the fermented coffee extracts (F2 and F3) although fermented coffee had lower mean overall quality ratings for the entire group of consumers. Therefore, the fermented coffee samples (F2 and F3) did not have lower acceptance ratings for all consumers; they were acceptable and showed higher acceptability for $39.4 \%$ of consumers. This result provides supporting evidence that fermentation does not have a negative influence on the consumer acceptance of coffee. Consumers are therefore segmented and another coffee product can be created for approximately $40 \%$ of coffee consumers. In addition, the high antioxidant activity and phenolic compounds in fermented coffee can be attractive to those consumers with moderate acceptance for fermented coffee. The consumer acceptance would also increase with awareness of the high antioxidant activity and phenolic compounds content as shown in a previous blind and informed consumer acceptance test for blueberry functional beverages [36].

\section{Conclusion}

Yeast fermentation of green coffee beans for $24 \mathrm{~h}$ was effective in fortifying the functionality of coffee by inducing a significant increase in antioxidant activity, TPC, and TFC. Yeast fermentation of green coffee beans causes bound phenolic compounds to be released after roasting. The consumer acceptance for the fermented coffee beans was slightly lower than for the controls. Fermentation might negatively influence the aroma and flavor of coffee extracts. However, the consumer segmentation revealed that approximately $39.4 \%$ of consumers preferred one of the fermented coffees (F3) more than the controls. Therefore, it can be concluded that yeast fermentation did not always generate a negative aroma and flavor for consumers. If fermentation was carried out with properly selected yeasts, fermented coffee can be attractive to coffee consumers, and coffee manufacturers can diversify their products with higher functionality.

\section{Conflicts of Interest}

The authors declare that they have no conflicts of interest.

\section{References}

[1] H. D. Vieira, "Coffee: The plant and its cultivation," in PlantParasitic Nematodes of Coffee, M. Souza, Ed., pp. 3-18, Springer, Dordrecht, Netherlands, 2008.

[2] "International Coffee Organization (ICO)," 2015, http://www .ico.org/trade_statistics.asp.

[3] P. Parras, M. Martínez-Tomé, A. M. Jiménez, and M. A. Murcia, "Antioxidant capacity of coffees of several origins brewed following three different procedures," Food Chemistry, vol. 102, no. 3, pp. 582-592, 2007.

[4] M. Pérez-Martínez, B. Caemmerer, M. P. de Peña, C. Concepción, and L. W. Kroh, "Influence of brewing method and acidity regulators on the antioxidant capacity of coffee brews," Journal of Agricultural and Food Chemistry, vol. 58, no. 5, pp. 2958-2965, 2010.

[5] I. Sánchez-González, A. Jiménez-Escrig, and F. Saura-Calixto, "In vitro antioxidant activity of coffees brewed using different procedures (Italian, espresso and filter)," Food Chemistry, vol. 90, no. 1-2, pp. 133-139, 2005. 
[6] J. R. Oliveira-Neto, S. G. Rezende, C. De Fátima Reis, S. R. Benjamin, M. L. Rocha, and E. De Souza Gil, "Electrochemical behavior and determination of major phenolic antioxidants in selected coffee samples," Food Chemistry, vol. 190, no. 1, Article ID 17651, pp. 506-512, 2016.

[7] J. A. Vignoli, M. C. Viegas, D. G. Bassoli, and M. D. T. Benassi, "Roasting process affects differently the bioactive compounds and the antioxidant activity of arabica and robusta coffees," Food Research International, vol. 61, no. 1, pp. 279-285, 2014.

[8] M. Richelle, I. Tavazzi, and E. Offord, "Comparison of the antioxidant activity of commonly consumed polyphenolic beverages (coffee, cocoa, and tea) prepared per cup serving," Journal of Agricultural and Food Chemistry, vol. 49, no. 7, pp. 3438-3442, 2001.

[9] R. Huxley, C. M. Y. Lee, F. Barzi et al., "Coffee, decaffeinated coffee, and tea consumption in relation to incident type 2 diabetes mellitus: a systematic review with meta-analysis," rchives of Internal Medicine, vol. 169, no. 22, pp. 2053-2063, 2009.

[10] E. Mostofsky, M. S. Rice, E. B. Levitan, and M. A. Mittleman, "Habitual coffee consumption and risk of heart failure a doseresponse meta-analysis," Circulation: Heart Failure, vol. 5, no. 4, pp. 401-405, 2012.

[11] R. Pulido, M. Hernñndez-García, and F. Saura-Calixto, "Contribution of beverages to the intake of lipophilic and hydrophilic antioxidants in the Spanish diet," European Journal of Clinical Nutrition, vol. 57, no. 10, pp. 1275-1282, 2003.

[12] S. A. Qureshi, A. C. Lund, M. B. Veierød et al., "Food items contributing most to variation in antioxidant intake; a crosssectional study among Norwegian women," BMC Public Health, vol. 14, no. 1, article no. 45, 2014.

[13] A. Svilaas, A. K. Sakhi, L. F. Andersen et al., "Intakes of antioxidants in coffee, wine, and vegetables are correlated with plasma carotenoids in humans," Journal of Nutrition, vol. 134, no. 3, pp. 562-567, 2004.

[14] B.-G. Kim, S.-Y. Choi, M.-R. Kim, H. J. Suh, and H. J. Park, "Changes of ginsenosides in Korean red ginseng (Panax ginseng) fermented by Lactobacillus plantarum M1," Process Biochemistry, vol. 45, no. 8, pp. 1319-1324, 2010.

[15] S.-I. Lim, C.-W. Cho, U.-K. Choi, and Y.-C. Kim, "Antioxidant activity and ginsenoside pattern of fermented white ginseng," Journal of Ginseng Research, vol. 34, no. 3, pp. 168-174, 2010.

[16] R. Jayabalan, S. Marimuthu, and K. Swaminathan, "Changes in content of organic acids and tea polyphenols during kombucha tea fermentation," Food Chemistry, vol. 102, no. 1, pp. 392-398, 2007.

[17] K.-C. Jeng, C.-S. Chen, Y.-P. Fang, R. C.-W. Hou, and Y.-S. Chen, "Effect of microbial fermentation on content of statin, GABA, and polyphenols in Pu-erh tea," Journal of Agricultural and Food Chemistry, vol. 55, no. 21, pp. 8787-8792, 2007.

[18] C. F. Silva, L. R. Batista, L. M. Abreu, E. S. Dias, and R. F. Schwan, "Succession of bacterial and fungal communities during natural coffee (Coffea arabica) fermentation," Food Microbiology, vol. 25, no. 8, pp. 951-957, 2008.

[19] H. H. Lim, S. Ji, H. S. Kwak et al., "Quality characteristics of coffee brewed from green beans soaked in mulberry (Morus bombycis) extract," Journal of the Korean Society of Food Science and Nutrition, vol. 44, no. 4, pp. 579-585, 2015.

[20] T. K. Ghose, "Measurement of cellulase activities," Pure and Applied Chemistry, vol. 59, no. 2, pp. 257-268, 1987.
[21] AOAC., Official Methods of Analysis, Association of Official Analytical Chemists, Gaithersburg, MD, USA, 18th edition edition, 2005.

[22] B. Ou, M. Hampsch-Woodill, and R. L. Prior, "Development and validation of an improved oxygen radical absorbance capacity assay using fluorescein as the fluorescent probe," Journal of Agricultural and Food Chemistry, vol. 49, no. 10, pp. 4619-4626, 2001.

[23] S. Marklund and G. Marklund, "Involvement of the superoxide anion radical in the autoxidation of pyrogallol and a convenient assay for superoxide dismutase," European Journal of Biochemistry, vol. 47, no. 3, pp. 469-474, 1974.

[24] V. L. Singleton, R. Orthofer, and R. M. Lamuela-Raventós, "Analysis of total phenols and other oxidation substrates and antioxidants by means of folin-ciocalteu reagent," Methods in Enzymology, vol. 299, pp. 152-178, 1999.

[25] V. Dewanto, X. Wu, and R. H. Liu, "Processed sweet corn has higher antioxidant activity," Journal of Agricultural and Food Chemistry, vol. 50, no. 17, pp. 4959-4964, 2002.

[26] H. J. MacFie, N. Bratchell, K. Greenhoff, and L. V. Vallis, "Designs to balance the effect of order of presentation and firstorder carry-over effects in hall tests," Journal of Sensory Studies, vol. 4, no. 2, pp. 129-148, 1989.

[27] C. I. Rodrigues, L. Marta, R. Maia, M. Miranda, M. Ribeirinho, and C. Máguas, "Application of solid-phase extraction to brewed coffee caffeine and organic acid determination by UV/HPLC," Journal of Food Composition and Analysis, vol. 20, no. 5, pp. 440-448, 2007.

[28] Y.-H. Pyo, T.-C. Lee, and Y.-C. Lee, "Effect of lactic acid fermentation on enrichment of antioxidant properties and bioactive isoflavones in soybean," Journal of Food Science, vol. 70, no. 3, pp. S215-S220, 2005.

[29] E. Sato, M. Kohno, H. Hamano, and Y. Niwano, "Increased anti-oxidative potency of garlic by spontaneous short-term fermentation," Plant Foods for Human Nutrition, vol. 61, no. 4, pp. 157-160, 2006.

[30] M. Shi, Y. Yang, Q. Wang, Y. Zhang, Y. Wang, and Z. Zhang, "Production of total polyphenol from fermented soybean curd residue by Lentinus edodes," International Journal of Food Science \& Technology, vol. 47, no. 6, pp. 1215-1221, 2012.

[31] Y.-K. Lee, S.-I. Lee, J.-S. Kim et al., "Antioxidant activity of green tea fermented with Monascus pilosus," Journal of Applied Biological Chemistry, vol. 55, no. 1, pp. 19-25, 2012.

[32] J.-Y. Shin, H. Kim, D.-G. Kim, G.-H. Baek, H.-S. Jeong, and K.-W. Yu, "Pharmacological activities of coffee roasted from fermented green coffee beans with fungal mycelia in solidstate culture," Journal of the Korean Society of Food Science and Nutrition, vol. 42, no. 3, pp. 487-496, 2013.

[33] L. C. Mendes, H. C. De Menezes, M. Aparecida, and A. P. Da Silva, "Optimization of the roasting of robusta coffee (C. canephora conillon) using acceptability tests and RSM," Food Quality and Preference, vol. 12, no. 2, pp. 153-162, 2001.

[34] H. S. Kwak, J. S. Seo, Y. Hur et al., "Influence of yeast strains on the physicochemical characteristics, methanol and acetaldehyde profiles and volatile compounds for Korean rice distilled spirit," Journal of the Institute of Brewing, vol. 121, no. 4, pp. 574-580, 2015.

[35] E. S. Oliveira, H. M. A. B. Cardello, E. M. Jeronimo, E. L. Rocha Souza, and G. E. Serra, "The influence of different yeasts on the fermentation, composition and sensory quality of cachaça," World Journal of Microbiology and Biotechnology, vol. 21, no. 5, pp. 707-715, 2005. 
[36] M. K. Kim and H. S. Kwak, "Influence of functional information on consumer liking and consumer perception related to health claims for blueberry functional beverages," International Journal of Food Science \& Technology, vol. 50, no. 1, pp. 70-76, 2015. 


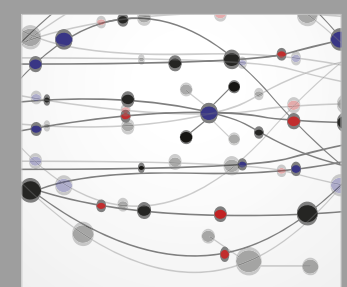

The Scientific World Journal
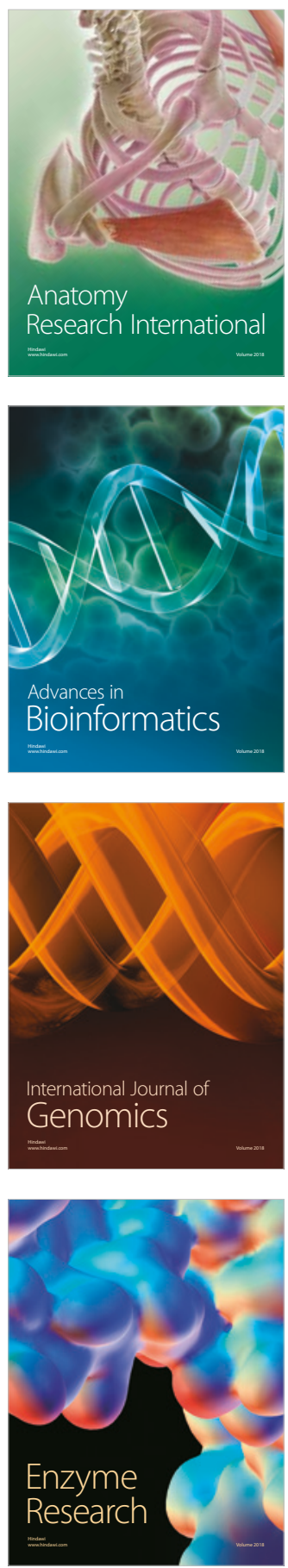
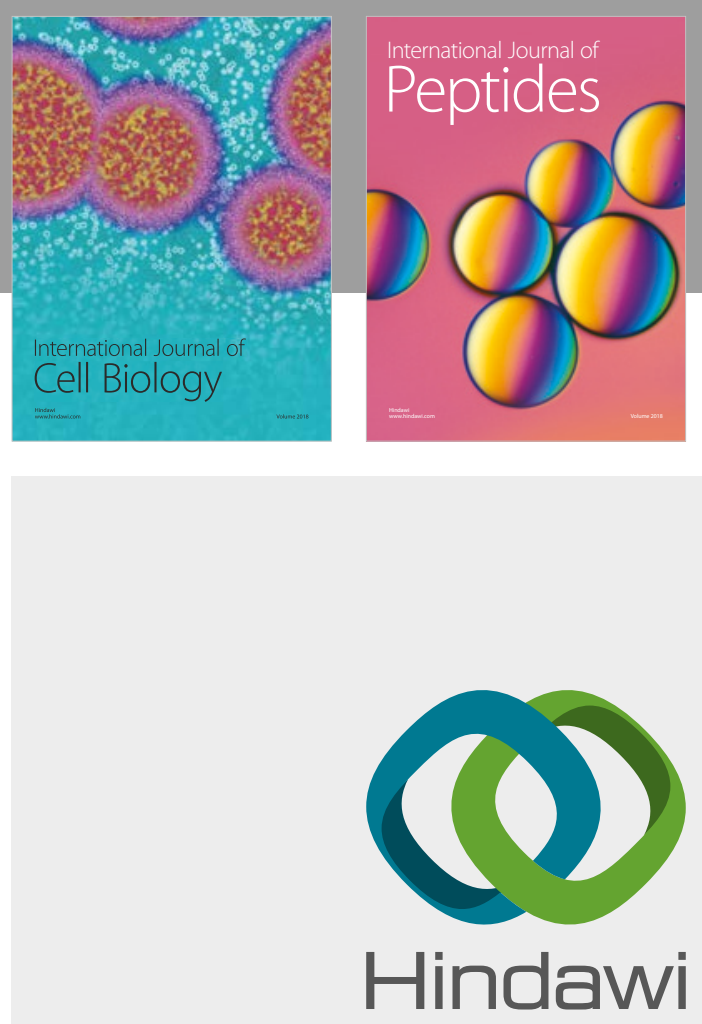

Submit your manuscripts at

www.hindawi.com
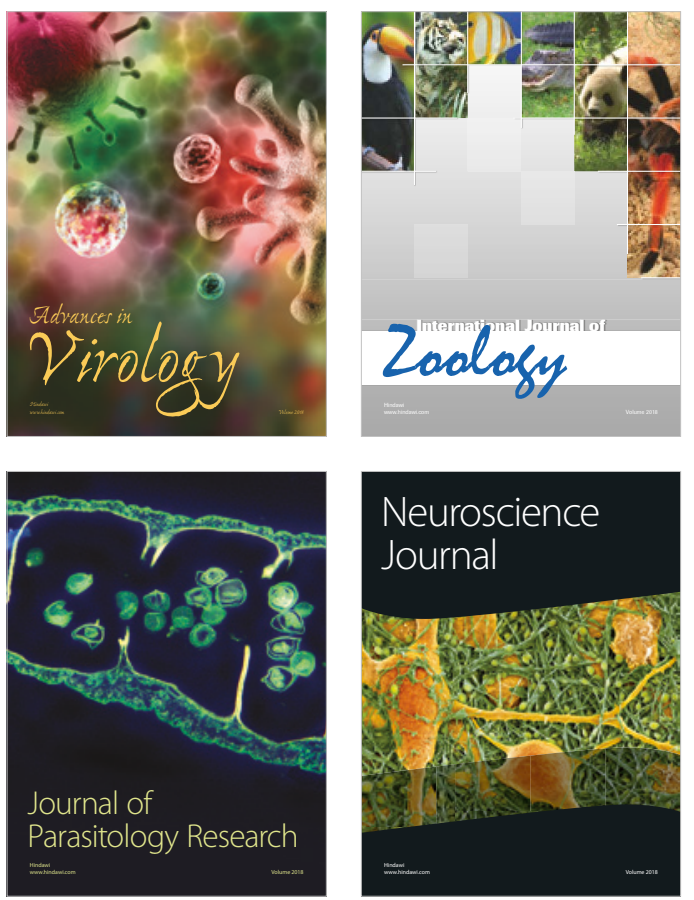
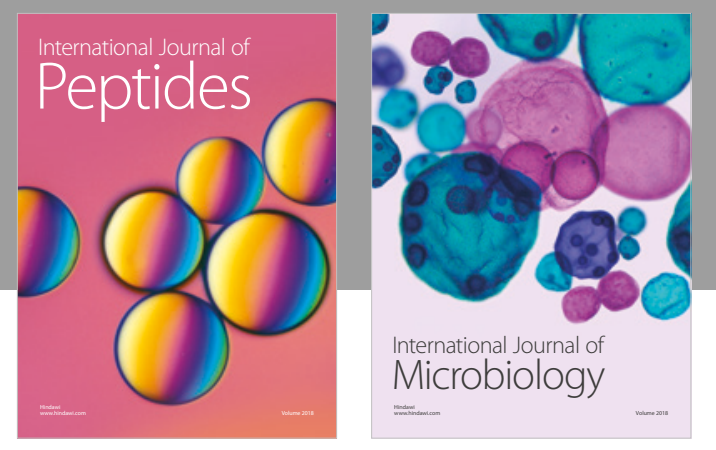

nternational Journal of Microbiology
Journal of
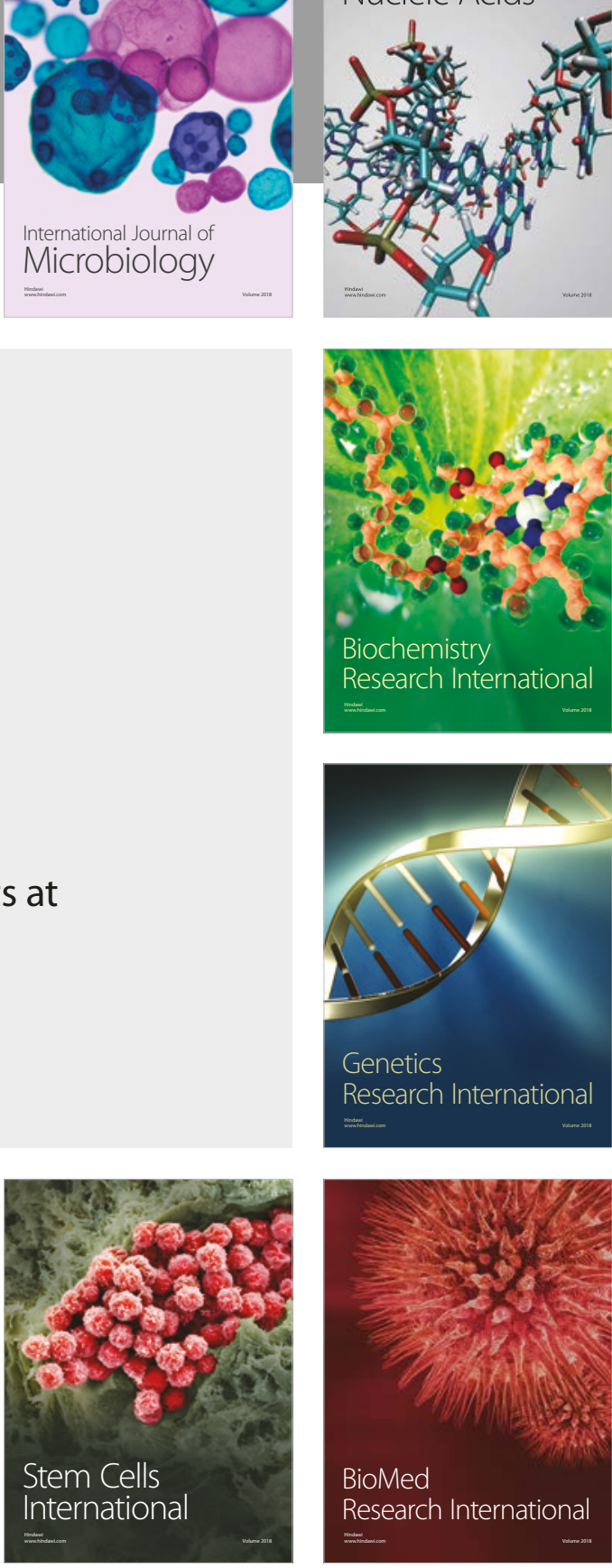
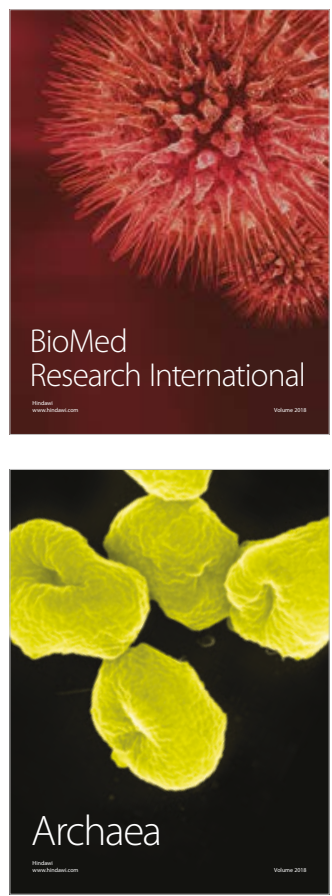